Article

\title{
Entropy-Based Hybrid Integration of Random Forest and Support Vector Machine for Landslide Susceptibility Analysis
}

\author{
Amol Sharma ${ }^{1, *(\mathbb{D})}$, Chander Prakash ${ }^{1} \mathbb{D}$ and V. S. Manivasagam ${ }^{2} \mathbb{D}$ \\ 1 Department of Civil Engineering, National Institute of Technology, Hamirpur 177005, Himachal Pradesh, \\ India; chandermanali@nith.ac.in \\ 2 Amrita School of Agricultural Sciences, Amrita Vishwa Vidyapeetham, J. P. Nagar, Arasampalayam, \\ Myleripalayam, Coimbatore 642109, Tamil Nadu, India; vs_manivasagam@cb.amrita.edu \\ * Correspondence: amol@nith.ac.in; Tel.: +91-701-8803-719
}

Citation: Sharma, A.; Prakash, C.; Manivasagam, V.S. Entropy-Based Hybrid Integration of Random Forest and Support Vector Machine for Landslide Susceptibility Analysis Geomatics 2021, 1, 399-416. https:// doi.org/10.3390/geomatics1040023

Academic Editor: Francesca Cigna

Received: 30 September 2021

Accepted: 22 October 2021

Published: 26 October 2021

Publisher's Note: MDPI stays neutral with regard to jurisdictional claims in published maps and institutional affiliations.

Copyright: (c) 2021 by the authors. Licensee MDPI, Basel, Switzerland. This article is an open access article distributed under the terms and conditions of the Creative Commons Attribution (CC BY) license (https:// creativecommons.org/licenses/by/ $4.0 /)$.

\begin{abstract}
Landslide susceptibility mapping is a crucial step in comprehensive landslide risk management. The purpose of the present study is to analyze the landslide susceptibility of Mandi district, Himachal Pradesh, India, based on optimum feature selection and hybrid integration of the Shannon entropy (SE) model with random forest (RF) and support vector machine (SVM) models. An inventory of 1723 rainfall-induced landslides was generated and randomly selected for training (1199; $70 \%)$ and validation $(524 ; 30 \%)$ purposes. A set of 14 relevant factors was selected and checked for multicollinearity. These factors were first ranked using Information Gain and Chi-square feature ranking algorithms. Furthermore, Wilcoxon Signed Rank Test and One-Sample T-Test were applied to check their statistical significance. An optimum subset of 11 landslide causative factors was then used for generating landslide susceptibility maps (LSM) using hybrid SE-RF and SE-SVM models. These LSM's were validated and compared using receiver operating characteristic (ROC) curves and performance matrices. The SE-RF performed better with training and validation accuracies of $96.93 \%$ and $88.94 \%$, respectively, compared with the SE-SVM model with training and validation accuracies of $94.05 \%$ and $82.4 \%$, respectively. The prediction matrices also confirmed that the SE-RF model is better and is recommended for the landslide susceptibility analysis of similar mountainous regions worldwide.
\end{abstract}

Keywords: landslide susceptibility; Shannon entropy; random forest; support vector machine; feature selection; performance matrices

\section{Introduction}

Landslides are one of the most devastating natural disasters inflicting death and destruction, especially in the mountainous regions, around the globe. Their occurrence can be attributed to the downward movement of soil mass or debris due to natural triggering factors like rainfall and earthquakes, or through anthropogenic activities like deforestation and road construction [1,2]. Landslides have affected 4.5 million people and have caused the death of 18,000 people worldwide [3]. The central Himalayan region of northern India also witnesses frequent landslides, especially in monsoon season. The state of Himachal Pradesh witnessed 18 major landslide incidences during the monsoon season of 2020. An estimated 20 buildings collapsed, and 44 people died due to these incidences, inflicting a revenue loss of $\$ \$ 57.5$ million to the state [4]. To reduce these losses, it is necessary to predict the potential landslide-prone areas in order to administer adequate response and emergency measures on time.

The landslide susceptibility analysis is considered a foremost tool for comprehensive landslide risk management $[5,6]$. The susceptibility analysis is considered a complex process. It is a readily perceived research area in recent times, and experts have proposed various techniques and methodologies in different geological and meteorological settings $[7,8]$. Using appropriate prediction models, the analysis involves zoning the area into potentially 
susceptible zones by generating landslide susceptibility maps (LSM) $[9,10]$. The predictive potential of these models depends on the accuracy of the landslide inventory, the relevance of the landslide thematic variables, and the type of landslide predictive models [11,12]. Any study related to landslides depends on the accuracy of the landslide inventory data collected and mapped $[13,14]$. This data can be prepared by satellite image processing, historical documentation and reports, and field surveys of landslide locations [15]. The occurrence of landslides in a region is influenced by various topographical, geological, hydrological, and anthropological factors. These factors are extracted and mapped using high-resolution remote sensing images and digital elevation models (DEM), and are characterized using geographical information system (GIS) [16-18]. Remote sensing benefits mapping landside areas according to the research demand using updated satellite images [19]. These satellite images and aerial photographs, being stereoscopic, provide three-dimensional perspectives for the characterization of landslides based on the spatial and temporal features of the region $[13,20]$. This spatial and temporal thematic dataset needs to be integrated with ground-based information. For this purpose, GIS is a widely accepted tool as it can store and analyze extensive data [21-23]. Landslide susceptibility mapping (LSM) is carried out using various statistical models to determine the frequency and probability of a landslide event [24]. Some commonly used models include frequency ratio (FR) [25-27], certainty factor (CF) [28-30], Shannon entropy (SE) [31-34], weight of index (WOI) [35,36], and evidential belief function (EBF) [37,38]. The disadvantages of statistical methods include lower predictive potential, simplifying complex relationships, and human interference during feature selection [8,39]. Machine learning (ML) techniques can minimize human interference and have the advantage of quantitatively analyzing factor dependence and continuous updating and reproducing datasets $[40,41]$. Some commonly applied ML techniques includes logistic regression (LR) [42-44], support vector machine (SVM) [45,46], decision trees (DT) [47,48], artificial neural network (ANN) [49-51], naïve Bayes (NB) [52,53], and random forest (RF) [54,55]. However, ML techniques also have limitations, including overfitting data and difficulty relating the results with existing scientific landslide theories. In recent times, several studies have been carried out using integrated statistical and ML techniques such as the SVM-IOE model [56], WOE and SVM technique [35], random subspace-based classification and regression tree (RSCART) [57], adaptive network-based fuzzy inference system with frequency ratio (FR-ANFIS) [12], and bivariate statistical-based kernel logistic regression (KLR) models with different kernel functions [58]. These studies suggested that the hybrid integration of models generally performed better than individual models. The present study aims to integrate the Shannon entropy (SE) statistical model with random forest (FR) and support vector machine (SVM) machine learning models using the optimum feature selection process for landslide susceptibility mapping. The next objective is to establish a systematic spatial relation between the selected features and landslide occurrences using landslide susceptibility maps. Finally, the accuracies of the SE-RF and SE-SVM models are analyzed using performance matrices and curves.

\section{Materials and Methods}

\subsection{Study Area and Landslide Inventory}

The Mandi district in the state of Himachal Pradesh, India, has geographic coordinates of $31^{\circ} 13^{\prime}$ and $32^{\circ} 05^{\prime}$ north latitudes and $76^{\circ} 37^{\prime}$ and $77^{\circ} 25^{\prime}$ east longitudes, and a $3951 \mathrm{~km}^{2}$ area (Figure 1). The area's elevation increases from west to east and south to north, and ranges between $500 \mathrm{~m}$ to $3400 \mathrm{~m}$. The area falls in the mid-hills-sub-humid zone and high hills temperate wet agro-climatic zone, which receives an annual average rainfall of $1240 \mathrm{~mm}$ and an annual temperature of $24^{\circ} \mathrm{C}$. The road density of the Mandi district is $155 \mathrm{~km}$ per $100 \mathrm{~km}^{2}$. The two major National Highways that run across the district's length and breadth are NH-3 (Atari-Manali-Leh) and NH-154 (Pathankot-Sundernagar-Bilaspur). The Beas river runs through the northern part of the district whereas the southern part is drained by the Satluj river. 


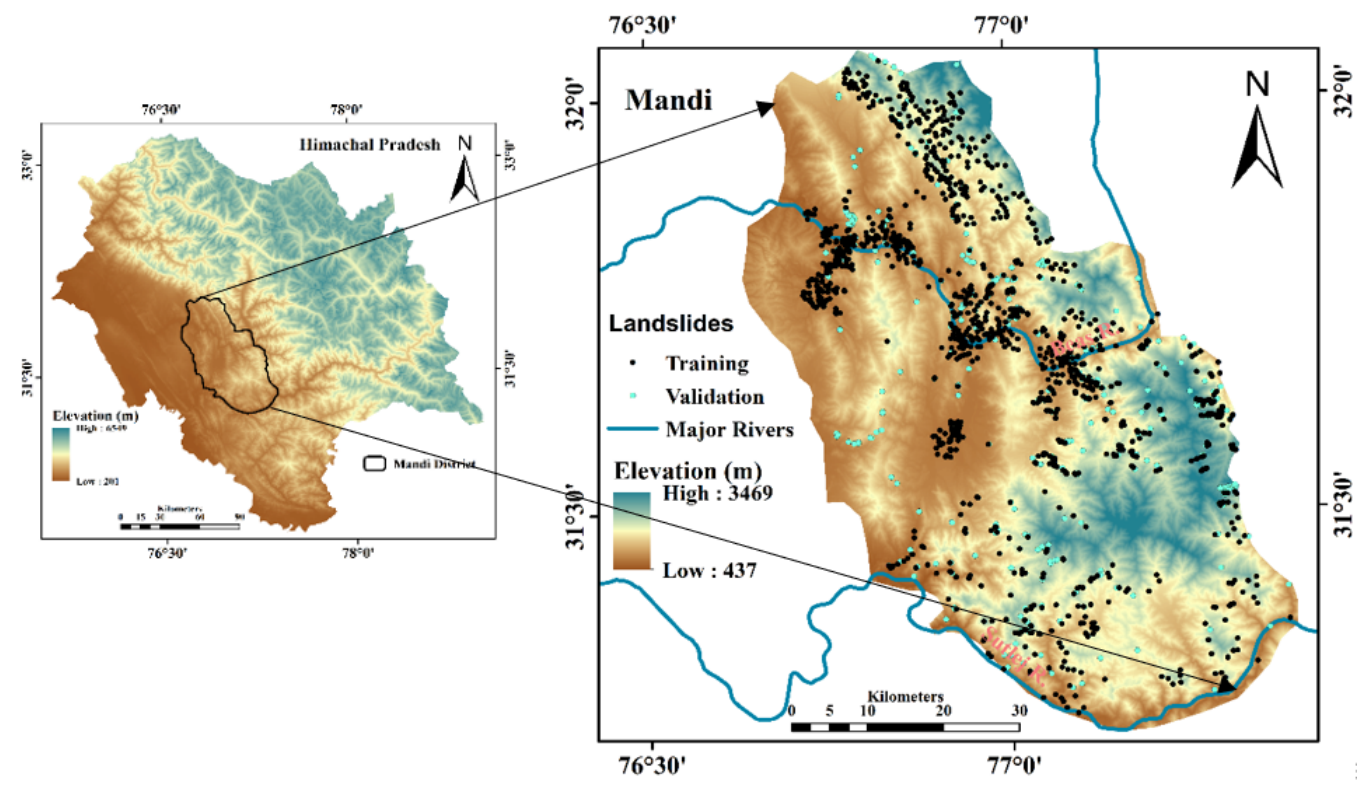

Figure 1. Study area: Mandi District, Himachal Pradesh, with landslide training and validation datasets.

The landslide inventory map's main elements include the geographical location of the landslide, its date and time of occurrence, triggering factors like heavy rainfall or earthquake, and damages incurred in terms of life and property [59]. The landslide inventory of the Mandi district was prepared by analyzing high-resolution satellite and Google Earth images, historical reports, and field surveys using handheld GPS (Figure 1). A total of 1723 rainfall-induced landslides and their location, type, and triggering factor, etc., were documented, with areas ranging from $26 \mathrm{~m}^{2}$ to $23,164 \mathrm{~m}^{2}$ and an average area of about $844 \mathrm{~m}^{2}$. Based on accepted terminology, the landslides were then categorized as shallow transitional slides with some deep rotational landslides [60]. Furthermore, it was found that a common triggering factor for all the landslides was rainfall during monsoon season and road construction activities in the region. The landslide inventory was further split into $1199(70 \%)$ training and $524(30 \%)$ validation datasets using a random sampling procedure in the ArcGIS environment.

\subsection{Landslide Causative Factors ( $L C F$ 's)}

The interaction between geological, morphometric, topographical, and hydrological factors in a region influences landslides' occurrence. Hence, the appropriate selection of these causative factors is a primary step in landslide susceptibility analysis [61]. In the present study, 14 landslide causative factors, namely, slope gradient, plan curvature, slope aspect, elevation, drainage density, lithology, geology, land use and landcover (LULC), normalized difference vegetation index (NDVI), soil characteristics, lineament density, stream power index (SPI), topographic wetness index (TWI), and distance from the roads, were identified using expert opinions and data availability. The list of various data sources is presented in Table 1. These factors were rasterized to a resolution of $30 \mathrm{~m}$ in the GIS environment. 
Table 1. Data purpose and sources for landslide susceptibility mapping.

\begin{tabular}{|c|c|c|c|}
\hline Data & Data Purpose & Data Source & Scale/Resolution \\
\hline $\begin{array}{l}\text { District Administration Mandi, } \\
\text { Himachal Pradesh }\end{array}$ & $\begin{array}{c}\text { Administrative boundary of } \\
\text { Mandi }\end{array}$ & $\begin{array}{l}\text { https: } \\
\text { / /hpmandi.nic.in/map-of-district/ } \\
\text { (accessed on 20 September 2020) }\end{array}$ & $1: 50,000$ \\
\hline $\begin{array}{l}\text { H.P. Disaster Revenue Reports } \\
\text { (2015-2019), Google Earth, } \\
\text { GSI-BHUKOSH, Handheld GPS }\end{array}$ & Landslide inventory & $\begin{array}{c}\text { https:/ /hpsdma.nic.in/ } \\
\text { https:/ / bhukosh.gsi.gov.in/ } \\
\text { (accessed on } 25 \text { September } 2020\end{array}$ & $1: 50,000$ \\
\hline ALOS-PALSAR DEM & $\begin{array}{l}\text { Slope, curvature, aspect, } \\
\text { elevation, drainage density, } \\
\text { and TWI }\end{array}$ & $\begin{array}{l}\text { https:/ / search.asf.alaska.edu } \\
\text { (accessed on } 12 \text { October 2020) }\end{array}$ & $12.5 \mathrm{~m}$ \\
\hline Landsat-8 OLI & NDVI and lineaments & $\begin{array}{l}\text { http:/ / earthexplored.usgs.gov } \\
\text { (accessed on } 7 \text { October 2020) }\end{array}$ & $30 \mathrm{~m}$ \\
\hline $\begin{array}{c}\text { Geological Survey of India (GSI), } \\
\text { BHUKOSH }\end{array}$ & Geology and lithology & $\begin{array}{l}\text { https:/ / bhukosh.gsi.gov.in/ } \\
\text { (accessed on } 17 \text { July 2020) }\end{array}$ & $1: 50,000$ \\
\hline $\begin{array}{c}\text { Ministry of Road Transport and } \\
\text { Highways (MoRTH) }\end{array}$ & Major roads of Mandi district & $\begin{array}{l}\text { https://morth.nic.in/ } \\
\text { (accessed on } 22 \text { July 2020) }\end{array}$ & $1: 50,000$ \\
\hline $\begin{array}{l}\text { National Bureau of Soil Survey } \\
\text { and Land Use Planning } \\
\text { (ICAR-NBSS and LUP) }\end{array}$ & $\begin{array}{c}\text { Soil-Type, depth, and } \\
\text { drainage of Mandi District }\end{array}$ & $\begin{array}{l}\text { https:/ / www.nbsslup.in/ } \\
\text { (accessed on } 19 \text { July 2020) }\end{array}$ & $1: 50,000$ \\
\hline
\end{tabular}

An ALOS-PALSAR Digital Elevation Model (DEM) with a $12.5 \mathrm{~m}$ resolution was used to derive the elevation, slope gradient, slope aspect, curvature, topographical wetness index (TWI), stream power index, and drainage density of the study area using ArcGIS software. The slope gradient of an area is defined as the rate of change of elevation over a distance in the direction of the steepest fall that influences landslides in a particular area [62]. The slope gradient map was classified as flat $\left(<15^{\circ}\right)$, moderate $\left(15-25^{\circ}\right)$, moderately steep $\left(25-35^{\circ}\right)$, steep $\left(35-45^{\circ}\right)$, and very steep $\left(>45^{\circ}\right)$. The plan curvature of the slope represents the direction of the maximum slope and has an essential role in landslide occurrence as it controls the inflow and outflow of the drainage networks of an area [63]. The curvature map of the area was divided into five categories: convex, slight convex, flat, slightly concave, and concave. The slope's aspect is the orientation of the slope, measured clockwise in degrees from 0 to 360, where 0 is north-facing, 90 is east-facing, 180 is south-facing, and 270 is westfacing. Aspect is again an essential parameter for better understanding the slope stability in a particular direction [64]. Elevation is extensively used in landslide susceptibility. Even though a direct relationship between landslide occurrences and elevation could not be established, it still affects other parameters like rainfall and seismicity [65]. The Beas river basin surrounds the northern part of the Mandi District. It is characterized by a lower elevation, including the Balh valley in the Mandi District. The southwestern part of the Mandi District is characterized by low to moderate elevation zones with elevations ranging from 600 to $1500 \mathrm{~m}$. The drainage density of an area influences the surface runoff and slope erosion potential [52]. The Beas and Satluj rivers in the Mandi District, and their tributaries and distributaries, drain the area well. Although most of the study area has a very low drainage density, there is still a considerable area with a moderate to high drainage density and significant landslides. TWI is used to quantify the hydrological impact of the drainage networks on the wetness/saturation of the soils on the slopes. The greater the value of the TWI, greater is the soil's water content, and the more significant is its hence tendency for erosion [66]. The TWI map was generated by the combined arithmetic applications of slope gradient and flow accumulation parameters, using TWI $=(\operatorname{Ln}(\mathrm{As}) / \operatorname{Tan}(\beta))$, where Ln is the natural $\log$, As is the flow accumulation, and $\beta$ is the slope gradient in radians. The TWI of the area was classified into the following five categories: very low, low, moderate, high, and very high. Lineament density is defined as the total length of all of the lineaments divided by the area under study. Stream power index (SPI) describes the potential of flow 
erosion of a particular point on the topographic surface. In a given catchment area, the amount of water contributed by the upslope area increases with the increase in the slope gradient. This, in turn, increases the SPI and risk of erosion at a given point on the surface. An SPI map of the study area was also prepared by the combined arithmetic application of morphometric variables, which includes the slope gradient and flow accumulation parameters using SPI = As $x \operatorname{Tan}(\beta)$. The lineament density was computed using the line density tool in the GIS environment. The Operational Land Imager (OLI) and Thermal Infrared Sensor (TRIS) of the Landsat- 8 satellite with 12-Band multispectral images with a 30-m resolution were procured from 2015 to 2020, from the first week of October to the last week of November, were considered adequate due to the availability of cloud-free data just after the monsoon season is over. The NDVI map is one of the most fundamental and widely accepted indexes to detect vegetation and landcover changes caused by infrastructural developmental activities [67]. NDVI provides information about landcover changes using the energy absorbed and emitted by the objects on the Earth's surface, and is prepared by image analysis techniques on high-resolution Landsat-8 images using the following: NDVI = (NIR - RED) / NIR + RED), where NIR (Near Infra-Red Band) and RED bands represent the spectral reflectance bands of the electromagnetic spectrum. The LULC characteristics of an area indicate the physical characteristics of the Earth's surface and the change brought due to human interference. Deforestation, intensive agriculture, and new infrastructure development may lead to soil and slide degradation, which are the main causative factors for landslide occurrences [35]. The LULC map of the area was generated using Landsat-8 images by the maximum likelihood classification method in ERDAS Imagine software. An area's geological and lithological boundaries are closely related to the slope and rock strength, and such boundaries may lead to increased landslide activity [61]. The study area lies within the lesser Himalayan region. The Jutog, Chail, Shah, and Tertiary group of rocks are predominant in the district. The oldest rocks belong to Jutog groups, whereas the youngest valley fills are of a recent age, comprising clay, sand, and gravel beds. The Jutog formation comprises slates, Schists, and Quartzite, with Hematite and magnetite bands included in Chail formation. The Granitic rocks are found to occur around the Karsog area. Thin bands of Slates are also found to occur. Salt grit, locally known as lokhan, is overlain by Mandi Darla volcanics [68]. The soil type is characterized by the percentage of sand, silt, and clay minerals present, configuring the soil's texture and hydraulic properties. Even though it is not straightforward to define the complex relationship between the soil's hydrological properties and the mechanics through which landslides occur, soils with a higher permeability still allow the water to flow through them, making them more susceptible to landslides. Additionally, different types of soils have different cohesion values. Therefore, the infiltrated water might erode the soils with lesser cohesion values [69]. Five soils were identified in the study area, along with their depth, drainage, and erosion properties. The road construction activities in mountainous regions result in loss of support and crack development due to an increased strain in the upper soil mass. In addition, road construction leads to a change in each area's natural drainage corridor [70]. Hence, landslide occurrences are more common along the road alignment. The distance to the roads of the study area was divided into six classes: 0-100, 100-200, 200-300, 300-400, 400-500, and >500 m. The thematic layers of landslide causative factors were prepared using Arc GIS 10.4.1 and GEOMATICA. The mathematical calculations for statistical and machine learning methods were carried out in SPSS software and integrated R-ArcGIS bridge for spatial data analysis.

In the landslide susceptibility analysis, landslide causative factors are usually selected based on the area's landslide categories, geological, and topographical characteristics [43]. As no definite guidelines are available for the optimum selection of these factors, many research studies selected these factors randomly or based on data availability. However, to avoid overfitting data and achieve the maximum predictive potential from the model, it is necessary to quantify and select the best-suited subset from the available factors and to remove non-essential factors with a low correlation to landslide occurrence [61]. Many 
researchers have used various techniques, like linear correlation, factor analysis, chi-square ranking, and multi-factor approach, to carry out feature selection process but encountered problems of excess time consumption and inability in order to decide the threshold for minimum factor inclusion in the model [71-74]. However, some studies have used a hybrid approach of combining feature ranking with a statistical significance test to select the optimum feature subset. The statistical significance indicates the level of confidence based on which a null hypothesis can be accepted or rejected. A hypothesis can only be accepted at a 95\% significance level $(p>0.05)$ for the systematic pairwise difference between the different model performances. A $\mathrm{k}$-fold cross-validation procedure is generally applied to split the dataset into subsets, allowing for different training samples for each process. In the present study, Chi-squared and information gain algorithms were used for feature ranking, logistic regression (LR) was used as the initial predictive model, and Wilcoxon's Signed-Rank test and One-Sample T-Test were used to measure the statistical significance level to obtain the optimum feature subset. The detailed methodology of the study is depicted in Figure 2.

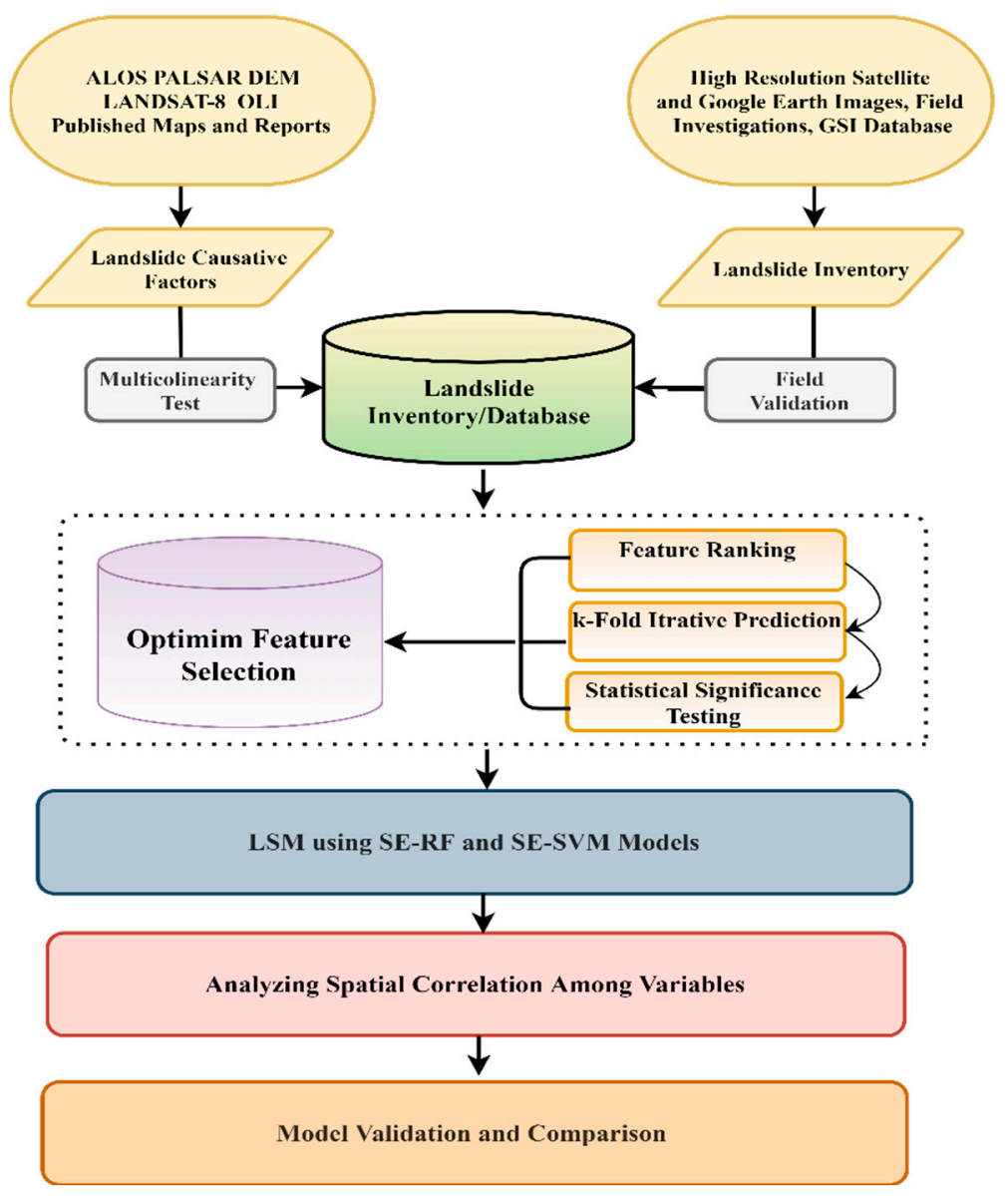

Figure 2. Flowchart depicting the methodology used in the study.

\subsection{Shannon Entropy (SE) Model}

The entropy of a system conceptually measures the degree of randomness, disorder, uncertainty, or instability of a system [6,33]. Claude Shannon, in 1948, developed the concept of entropy to analyze a fundamental communication problem of information theory, but later, this theory was found to be helpful in other areas. The concept of the entropy of landslides refers to the probability distribution of landslide occurrences concerning its frequency in each subclass of landslide causative factors [34,63]. Thus, 
entropy values can be used to calculate the relative weights of the data based on an index system using the following equations

$$
\begin{gathered}
E_{j}=-\sum_{i=1}^{N_{j}} P_{i j} \log _{2} P_{i j}, j=1, \ldots, n \\
E_{j \max }=\log _{2} N_{j}, j=\text { number of subclasses } \\
H_{j}=\left(E_{j \max }-\frac{E_{j}}{E_{j \max }}\right), H=(0,1), j=1, \ldots, n \\
W_{j}=H_{j} * F R
\end{gathered}
$$

where $E_{j}$ and $E_{j m a x}$ are the entropy values, $H_{j}$ is the information coefficient, and $N_{j}$ is the number of classes in each landslide causative factor. $\mathrm{W}_{\mathrm{j}}$ is the relative weight assigned to each landslide causative factor and FR is the frequency ratio value.

\subsection{Random Forest (RF) Model}

The RF model is a supervised learning algorithm that combines decision tree predictors. Each tree has randomly sampled independent data, and each tree fits independently in the data subset, achieved by splitting existing samples and regenerating random new samples using bootstrapping [75]. The RF model is a widely used model for regression and classification problems. It provides a high prediction accuracy, low errors, and can reduce the risk of overfitting $[42,54]$. To achieve good model performance and minimize the errors in the RF model, three hyperparameters are defined, namely: (i) the number of trees to be grown/combined (ntree), (iii) the maximum number of features to be considered at each split (mtree), and (iv) the size of the terminal nodes (nodesize).

\subsection{Support Vector Machine (SVM) Model}

SVM is a machine learning algorithm based on statistical learning and structural risk minimization theory [76]. The primary aim of SVM is to separate the non-linear dataset using an optimal hyperplane into two sample classes. The optimal classification hyperplane maximizes the margin of separation and splits the dataset points as \pm 1 , where +1 refers to the presence and -1 refers to the absence of point on the classification hyperplane. The distance between the training points adjoining the classification hyperplane (support vectors) is known as the classification margin [77]. The activation kernel function transforms non-linear data into a higher dimensional feature space for linear classification. The kernel functions can be classified as linear, polynomial, radial, and sigmoid. Previous studies used these radial basis kernels, as well as polynomial kernel functions, the most in the landslide susceptibility analysis $[78,79]$. The optimum hyperplane is generated using the decision function $f(x)=(\omega . \phi(x))+b$, where $\omega$ represents the coefficient vector defining the orientation of the classification hyperplane, $\phi(x)$ is the input sample $x$ converted to high dimensional feature space, and $b$ is the offset of hyperplane taken from origin.

\section{Results}

\subsection{Multicollinearity Analysis}

A multicollinearity test was conducted to identify the interdependence among the landslide causative factors. Any collinearity among variables can result in errors in output and decrease the model's predictive potential [80]. Variance inflation factor (VIF) values $>$ 10 or tolerance values $<0.1$ suggest the problem of collinearity among the independent variables. Out of the 14 landslide causative factors initially selected for analysis, it was found that all factors have acceptable values of VIF and tolerance (Table 2). Hence, all 14 landslide causative factors were deemed suitable for further analysis of the optimum feature selection and landslide susceptibility analysis. 
Table 2. Multicollinearity coefficients for landslide causative factors.

\begin{tabular}{ccc}
\hline \multirow{2}{*}{ Model } & \multicolumn{2}{c}{ Collinearity Statistics } \\
\cline { 2 - 3 } & Tolerance & VIF \\
\hline Slope & 0.798 & 3.658 \\
Aspect & 0.557 & 2.784 \\
Curvature & 0.217 & 5.633 \\
Elevation & 0.451 & 2.741 \\
Drainage Density & 0.751 & 5.214 \\
Lineament Density & 366 & 7.212 \\
Geology & 0.421 & 1.322 \\
NDVI & 0.257 & 6.369 \\
Soil & 0.785 & 4.321 \\
Roads & 0.741 & 2.357 \\
TWI & 0.679 & 4.212 \\
\hline
\end{tabular}

\subsection{Optimum Selection of LCF's}

In the present study, landslide causative factors' quality and usefulness were determined using information gain and Chi-square ranking algorithms. The logistic regression (LR) model was applied iteratively to access the prediction capabilities of feature datasets with an additional feature in each step.

A k-fold method was applied to split the landslide inventory dataset into 10 subsets to produce a new training dataset for each iterative step. It can be observed from Table 3 that both these methods produced different weights. In the next step, the Wilcoxon signed-rank test and One-Sample T-Test were applied as a statistical significance test for a pairwise comparison of the prediction models.

Table 3. Feature weights and order using feature ranking algorithms.

\begin{tabular}{cccc}
\hline \multicolumn{2}{c}{ Information Gain } & \multicolumn{2}{c}{ Chi-Squared } \\
\hline TWI & 0.301 & Distance to Roads & 0.579 \\
Drainage Density & 0.247 & TWI & 0.447 \\
Distance to Roads & 0.158 & Slope Gradient & 0.438 \\
NDVI & 0.147 & Drainage Density & 0.301 \\
Plan Curvature & 0.121 & Soil & 0.295 \\
Slope Gradient & 0.123 & Geology & 0.278 \\
Geology & 0.097 & Elevation & 0.199 \\
Elevation & 0.082 & Slope Aspect & 0.154 \\
Slope Aspect & 0.065 & NDVI & 0.125 \\
Soil & 0.047 & Plan Curvature & 0.081 \\
Lineament Density & 0.031 & Lineament Density & 0.065 \\
SPI & 0.020 & LULC & 0.042 \\
Lithology & 0.012 & Lithology & 0.015 \\
LULC & 0.010 & SPI & 0.008 \\
\hline
\end{tabular}

The results of all of the possible model scenarios are shown in Table 4. It was observed that Case- 4 and Model- 11 had relevant features, a high prediction performance, and a high confidence level, and were selected as the optimum feature subsets for further analyses. The selected features are shown in Figure 3. 

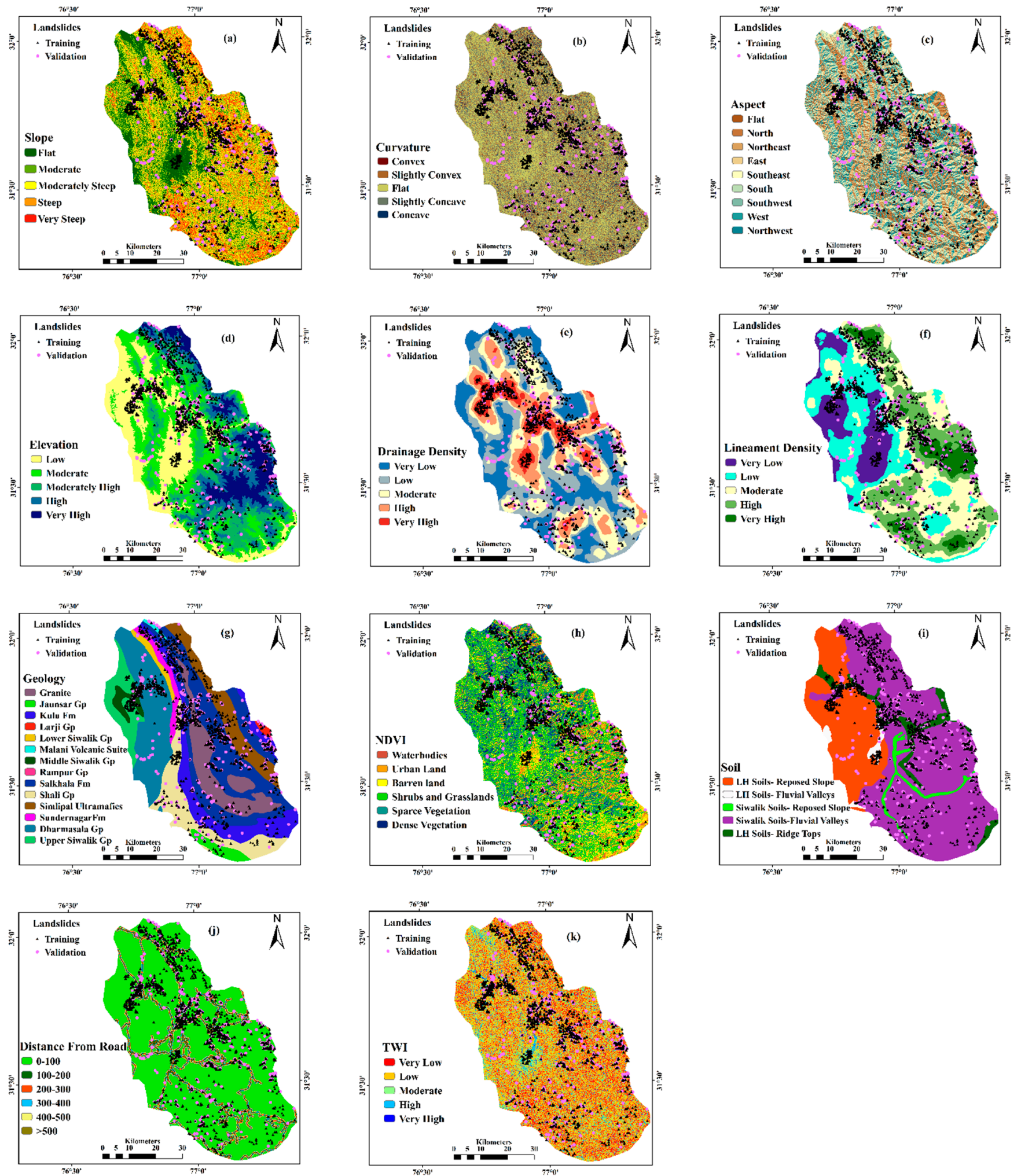

Figure 3. Landslide causative factors: (a) slope gradient, (b) curvature, (c) slope aspect, (d) elevation, (e) drainage density, (f) lineament density, (g) geology, (h) NDVI, (i) soil, (j) distance from roads, and (k) TWI. 
Table 4. Optimum feature subset using the feature selection process.

\begin{tabular}{|c|c|c|c|c|}
\hline $\begin{array}{l}\text { Feature Ranking } \\
\text { Methods }\end{array}$ & Case No. & Statistical Tests & $\begin{array}{l}\text { Model and } \\
\text { Subset Size }\end{array}$ & Features in the Optimum Subset \\
\hline \multirow{2}{*}{ Information Gain } & Case-1 & One Sample T-Test & Model-12 & $\begin{array}{c}\text { Slope; Aspect; Curvature; Elevation; Drainage } \\
\text { Density; Lithology; NDVI; LULC; Soil; SPI; TWI } \\
\text { Distance to Roads }\end{array}$ \\
\hline & Case-2 & $\begin{array}{c}\text { Wilcoxon Signed-Rank } \\
\text { Test }\end{array}$ & Model-11 & $\begin{array}{c}\text { Slope; Aspect; Curvature; Elevation; Drainage } \\
\text { Density; Geology; NDVI; Lineament Density; SPI; } \\
\text { TWI; Distance from Roads }\end{array}$ \\
\hline \multirow[b]{2}{*}{ Chi-Squared } & Case-3 & One Sample T-Test & Model-9 & $\begin{array}{l}\text { Slope; Curvature; Drainage Density; Geology; LULC; } \\
\text { Soil; Lineament Density; SPI; Distance to Roads }\end{array}$ \\
\hline & Case-4 & $\begin{array}{c}\text { Wilcoxon Signed-Rank } \\
\text { Test }\end{array}$ & Model-11 & $\begin{array}{c}\text { Slope; Aspect; Curvature; Elevation; Drainage } \\
\text { Density; Geology; NDVI; Soil; Lineament Density; } \\
\text { TWI; Distance from Roads }\end{array}$ \\
\hline
\end{tabular}

\subsection{LSM Using SE-RF Model}

The Ej values calculated for the Shannon entropy model were used to reclassify the subsets of landslide causative factors, and each factor was assigned a relative $\mathrm{Wj}$ value (Table 5). The landslide inventory data were split into 10-folds using the k-fold cross-validation method. These factors were then used as inputs for the FR model. The hyperparameters for the RF model were taken as ntree $=250$, mtree $=5$, and nodesize $=5$. The LSM SE-RF produced was classified into five susceptibility classes, as follows: very low (0-0.196), low (0.196-0.372), moderate (0.372-0.552), high (0.552-0.745), and very high (0.745-1). The percentage of area in each susceptibility class was calculated as very low $(22.47 \%)$, low $(23.72 \%)$, moderate $(22.12 \%)$, high $(17.51 \%)$, and very high $(14.17 \%$; Figure $4 \mathrm{a})$.

Table 5. Spatial correlation between landslide occurrence and landslide causative factors.

\begin{tabular}{|c|c|c|c|c|c|c|c|}
\hline & \multirow{2}{*}{ Class Pixels } & \multirow{2}{*}{$\begin{array}{l}\text { Percent of } \\
\text { Pixels }\end{array}$} & \multirow{2}{*}{$\begin{array}{l}\text { Landslide } \\
\text { Pixels }\end{array}$} & \multirow{2}{*}{$\begin{array}{l}\text { Percent of } \\
\text { Pixels }\end{array}$} & \multirow{2}{*}{$\begin{array}{c}\begin{array}{c}\text { Frequency } \\
\text { Ratio }\end{array} \\
\text { FR Values }\end{array}$} & \multicolumn{2}{|c|}{ Shanon Entropy } \\
\hline & & & & & & Pij & $\mathbf{W j}$ \\
\hline \multicolumn{8}{|l|}{$\begin{array}{c}\text { Landslide Causative } \\
\text { Factors }\end{array}$} \\
\hline \multicolumn{8}{|l|}{ Slope Gradient (Degree) } \\
\hline Flat $\left(<15^{\circ}\right)$ & 435,014 & 0.102 & 9 & 0.008 & 0.079 & 0.016 & \\
\hline Moderate $\left(15-25^{\circ}\right)$ & 948,259 & 0.222 & 85 & 0.076 & 0.341 & 0.069 & \\
\hline Moderately Steep $\left(25-35^{\circ}\right)$ & $1,374,272$ & 0.322 & 304 & 0.271 & 0.842 & 0.170 & 0.093 \\
\hline Steep $\left(35-45^{\circ}\right)$ & $1,047,813$ & 0.245 & 490 & 0.437 & 1.780 & 0.359 & \\
\hline Very Steep $\left(>45^{\circ}\right)$ & 466,470 & 0.109 & 234 & 0.209 & 1.910 & 0.386 & \\
\hline \multicolumn{8}{|l|}{ Plan Curvature } \\
\hline Convex $(-45--25)$ & 94,610 & 0.022 & 55 & 0.049 & 2.213 & 0.299 & \\
\hline Slight Convex $(-25--5)$ & 711,548 & 0.167 & 407 & 0.363 & 2.178 & 0.294 & \\
\hline Flat $(-5-5)$ & $1,953,189$ & 0.457 & 254 & 0.226 & 0.495 & 0.093 & 0.033 \\
\hline Slight Concave (5-25) & $1,346,104$ & 0.315 & 233 & 0.208 & 0.659 & 0.089 & \\
\hline Concave (25-50) & 166,377 & 0.039 & 73 & 0.065 & 1.671 & 0.225 & \\
\hline \multicolumn{8}{|l|}{ Slope Aspect } \\
\hline Flat & 33,660 & 0.008 & 4 & 0.004 & 0.452 & 0.054 & \\
\hline North & 484,657 & 0.113 & 126 & 0.112 & 0.990 & 0.119 & \\
\hline Northeast & 515,422 & 0.121 & 115 & 0.102 & 0.849 & 0.102 & \\
\hline East & 497,821 & 0.117 & 81 & 0.072 & 0.619 & 0.074 & \\
\hline Southeast & 503,993 & 0.118 & 108 & 0.096 & 0.816 & 0.098 & 0.013 \\
\hline South & 545,067 & 0.128 & 175 & 0.156 & 1.222 & 0.147 & \\
\hline Southwest & 647,098 & 0.151 & 238 & 0.212 & 1.400 & 0.168 & \\
\hline West & 546,964 & 0.128 & 195 & 0.174 & 1.357 & 0.163 & \\
\hline Northwest & 497,146 & 0.116 & 80 & 0.071 & 0.613 & 0.074 & \\
\hline
\end{tabular}


Table 5. Cont

\begin{tabular}{|c|c|c|c|c|c|c|c|}
\hline & \multirow{2}{*}{ Class Pixels } & \multirow{2}{*}{$\begin{array}{l}\text { Percent of } \\
\text { Pixels }\end{array}$} & \multirow{2}{*}{$\begin{array}{l}\text { Landslide } \\
\text { Pixels }\end{array}$} & \multirow{2}{*}{$\begin{array}{l}\text { Percent of } \\
\text { Pixels }\end{array}$} & \multirow{2}{*}{$\begin{array}{c}\begin{array}{c}\text { Frequency } \\
\text { Ratio }\end{array} \\
\text { FR Values }\end{array}$} & \multicolumn{2}{|c|}{ Shanon Entropy } \\
\hline & & & & & & $\mathbf{P i j}$ & $\mathbf{W j}$ \\
\hline \multicolumn{8}{|l|}{ Elevation (m) } \\
\hline Low (400-1000) & 995,824 & 0.233 & 212 & 0.189 & 0.811 & 0.188 & \multirow{5}{*}{0.066} \\
\hline Moderate (1000-1500) & $1,624,309$ & 0.380 & 266 & 0.237 & 0.623 & 0.144 & \\
\hline $\begin{array}{c}\text { Moderately High } \\
(1500-2000)\end{array}$ & $1,028,156$ & 0.241 & 539 & 0.480 & 1.996 & 0.462 & \\
\hline High (2000-2500) & 537,465 & 0.126 & 101 & 0.090 & 0.715 & 0.166 & \\
\hline Very High (2500-3500) & 86,074 & 0.020 & 4 & 0.004 & 0.177 & 0.041 & \\
\hline \multicolumn{8}{|l|}{ Drainage Density } \\
\hline Very Low $(0-0.6)$ & $1,299,831$ & 0.305 & 150 & 0.134 & 0.439 & 0.017 & \multirow{5}{*}{0.269} \\
\hline Low $(0.6-1.2)$ & $1,908,487$ & 0.448 & 229 & 0.204 & 0.456 & 0.018 & \\
\hline Moderate (1.2-1.8) & 877,782 & 0.206 & 337 & 0.300 & 1.459 & 0.058 & \\
\hline High (1.8-2.4) & 179,820 & 0.042 & 393 & 0.350 & 8.307 & 0.321 & \\
\hline Very High (2.4-3.0) & 5908 & 0.001 & 23 & 0.020 & 14.797 & 0.586 & \\
\hline \multicolumn{8}{|l|}{ Lineament Density } \\
\hline Very Low $(-0.1-0.3)$ & 585,993 & 0.138 & 67 & 0.060 & 0.434 & 0.081 & \multirow{5}{*}{0.048} \\
\hline Low $(0.3-0.6)$ & $1,093,925$ & 0.257 & 113 & 0.101 & 0.392 & 0.073 & \\
\hline Moderate (0.6-0.9) & $1,109,204$ & 0.260 & 329 & 0.293 & 1.126 & 0.211 & \\
\hline High (0.9-1.2) & $1,085,918$ & 0.255 & 407 & 0.363 & 1.423 & 0.266 & \\
\hline Very High (1.2-1.6) & 396,788 & 0.093 & 206 & 0.184 & 1.971 & 0.369 & \\
\hline \multicolumn{8}{|l|}{ Geology } \\
\hline Larji Group & 17,112 & 0.004 & 6 & 0.005 & 1.335 & 0.115 & \multirow{14}{*}{0.060} \\
\hline Shali Group & 480,871 & 0.113 & 99 & 0.088 & 0.784 & 0.068 & \\
\hline Jaunsar Group & 90,819 & 0.021 & 6 & 0.005 & 0.252 & 0.022 & \\
\hline Middle Siwalik Group & 77,936 & 0.018 & 37 & 0.033 & 1.808 & 0.156 & \\
\hline Salkhala Group & $1,020,010$ & 0.239 & 326 & 0.291 & 1.217 & 0.105 & \\
\hline $\begin{array}{c}\text { Hajaribagh Granite and } \\
\text { Pegmatite }\end{array}$ & 481,719 & 0.113 & 77 & 0.069 & 0.609 & 0.052 & \\
\hline $\begin{array}{c}\text { Dharmasala Group, } \\
\text { Dagshai and Kasauli } \\
\text { Formations }\end{array}$ & 761,109 & 0.178 & 186 & 0.070 & 1.679 & 0.145 & \\
\hline Upper Siwalik Group & 258,408 & 0.060 & 4 & 0.004 & 0.059 & 0.005 & \\
\hline Rampur Group & 2779 & 0.001 & 0 & 0.000 & 0.000 & 0.000 & \\
\hline Lower Siwalik Group & 61,338 & 0.014 & 3 & 0.003 & 0.186 & 0.016 & \\
\hline Sundernagar Formation & 100,192 & 0.023 & 33 & 0.119 & 0.650 & 0.056 & \\
\hline Malani Volcanic Suite & 15,813 & 0.004 & 1 & 0.007 & 0.112 & 0.010 & \\
\hline Simlipal Ultramafics & 368,975 & 0.086 & 144 & 0.128 & 1.486 & 0.128 & \\
\hline Kulu Formation & 534,747 & 0.125 & 200 & 0.178 & 1.424 & 0.123 & \\
\hline \multicolumn{8}{|l|}{ NDVI } \\
\hline Waterbodies $(-0.15-0.015)$ & 16,242 & 0.004 & 33 & 0.029 & 7.736 & 0.574 & \multirow{6}{*}{0.121} \\
\hline Urban $(0.015-0.14)$ & 492,012 & 0.115 & 286 & 0.255 & 2.213 & 0.164 & \\
\hline Barren Land (0.14-0.18) & 470,706 & 0.110 & 152 & 0.135 & 1.230 & 0.091 & \\
\hline $\begin{array}{c}\text { Shrubs and Grassland } \\
(0.18-0.27)\end{array}$ & $1,933,318$ & 0.453 & 399 & 0.356 & 0.786 & 0.058 & \\
\hline $\begin{array}{c}\text { Sparse Vegetation } \\
(0.27-0.36)\end{array}$ & $1,204,917$ & 0.282 & 219.000 & 0.195 & 0.692 & 0.051 & \\
\hline $\begin{array}{c}\text { Dense Vegetation } \\
\quad(0.36-0.74)\end{array}$ & 154,633 & 0.036 & 33 & 0.029 & 0.813 & 0.060 & \\
\hline
\end{tabular}


Table 5. Cont.

\begin{tabular}{|c|c|c|c|c|c|c|c|}
\hline & \multirow{2}{*}{ Class Pixels } & \multirow{2}{*}{$\begin{array}{l}\text { Percent of } \\
\text { Pixels }\end{array}$} & \multirow{2}{*}{$\begin{array}{l}\text { Landslide } \\
\text { Pixels }\end{array}$} & \multirow{2}{*}{$\begin{array}{l}\text { Percent of } \\
\text { Pixels }\end{array}$} & \multirow{2}{*}{$\begin{array}{c}\begin{array}{c}\text { Frequency } \\
\text { Ratio }\end{array} \\
\text { FR Values }\end{array}$} & \multicolumn{2}{|c|}{ Shanon Entropy } \\
\hline & & & & & & $\mathbf{P i j}$ & $\mathbf{W j}$ \\
\hline \multicolumn{8}{|l|}{ Soil } \\
\hline $\begin{array}{l}\text { Lesser Himalayan Soils of } \\
\text { Side/Reposed Slopes }\end{array}$ & $2,736,453$ & 0.641 & 899 & 0.801 & 1.251 & 0.289 & \\
\hline $\begin{array}{l}\text { Lesser Himalayan Soils of } \\
\text { Fluvial Valleys }\end{array}$ & 280,750 & 0.066 & 124 & 0.111 & 1.682 & 0.389 & 0.075 \\
\hline $\begin{array}{c}\text { Siwaliks Soils of } \\
\text { Side/Reposed Slopes }\end{array}$ & $1,083,902$ & 0.254 & 79 & 0.070 & 0.278 & 0.064 & \\
\hline $\begin{array}{c}\text { Siwaliks Soils of Fluvial } \\
\text { Valleys }\end{array}$ & 62,713 & 0.015 & 16 & 0.014 & 0.971 & 0.225 & \\
\hline $\begin{array}{l}\text { Lesser Himalayas Soils of } \\
\text { Summits and Ridge Tops }\end{array}$ & 108,010 & 0.025 & 4 & 0.004 & 0.141 & 0.033 & \\
\hline \multicolumn{8}{|l|}{ TWI } \\
\hline Very Low (0.00-4.00) & $3,192,586$ & 0.747 & 349 & 0.311 & 0.416 & 0.004 & \\
\hline Low (4.00-10.00) & $1,031,330$ & 0.241 & 436 & 0.389 & 1.610 & 0.014 & \\
\hline Moderate (10.00-16.00) & 37,036 & 0.009 & 208 & 0.185 & 21.383 & 0.182 & 0.140 \\
\hline High (16.00-22.00) & 9038 & 0.002 & 105 & 0.094 & 44.232 & 0.377 & \\
\hline Very High (22.00-28.00) & 1838 & 0.000 & 24 & 0.021 & 49.715 & 0.424 & \\
\hline \multicolumn{8}{|l|}{ Distance from Road (m) } \\
\hline $0-100$ & 240,721 & 0.056 & 406 & 0.362 & 6.421 & 0.359 & \multirow{6}{*}{0.082} \\
\hline 100-200 & 196,740 & 0.046 & 297 & 0.265 & 5.747 & 0.321 & \\
\hline $200-300$ & 172,030 & 0.040 & 111 & 0.099 & 2.456 & 0.137 & \\
\hline $300-400$ & 156,805 & 0.037 & 80 & 0.071 & 1.942 & 0.109 & \\
\hline $400-500$ & 145,918 & 0.034 & 43 & 0.038 & 1.122 & 0.063 & \\
\hline$>500$ & $3,359,614$ & 0.787 & 185 & 0.165 & 0.210 & 0.012 & \\
\hline
\end{tabular}
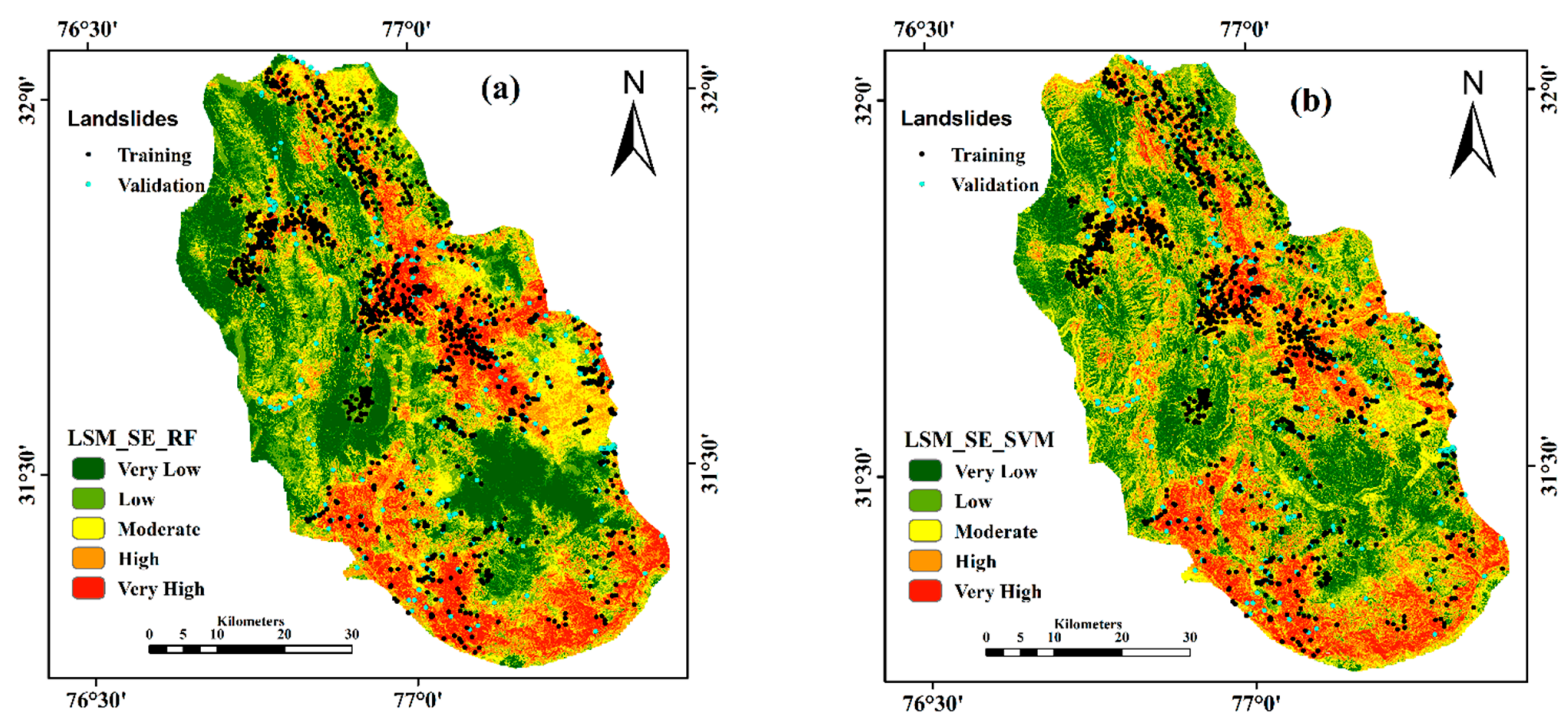

Figure 4. Landslide susceptibility maps: (a) SE-RF model and (b) SE-SVM model.

\subsection{LSM Using SE-SVM Model}

The $10 \mathrm{k}$-fold cross-validation dataset and landslide causative factors reclassified using SE model factors were considered as an input in the radial kernel-based SVM algorithm for calculating the LSM $\mathrm{SE}_{\mathrm{SVM}}$ values. These values ranged from 0 to 1 , where values closer to 0 indicated a lower probability of landslide occurrence and values closer to 1 indicated a higher probability of landslide occurrence. The LSM produced using the SE-SVM model was classified into five categories, namely very low (0-0.349), low (0.349-0.450), moderate 
(0.450-0.556), high (0.556-0.674), and very high (0.674-1) (Figure 4b), using the natural breaks classification method in a GIS environment. The LSM SE-SVM map analysis indicated that the study area percentage was very low, low, moderate, high, and very high, with $17.76 \%, 24.35 \%, 26.12 \%, 19.28 \%$, and $12.49 \%$, respectively (Figure $4 \mathrm{~b}$ ).

It was observed that the $\mathrm{Wj}$ values were the highest for the drainage density (0.269), TWI (0.140), and NDVI (0.121), and the ranking algorithms also suggested that these features had high ranking coefficients. Hence, these were identified as the primary factors responsible for higher landslide susceptibility in the study area.

\subsection{Performance and Validation of Models}

In the present study, the predictive performance of the hybrid LSM models was evaluated using various statistical and visual performance metrics. The confusion matrix is generally used in classification problems. It represents the counts from actual and predicted values using true positive (TP), true negative (TN), false positive (FP), and false-negative (FN) values, where TP indicates the number of actual landslide pixels classified accurately, TN indicates the number of non-landslide pixels classified accurately, FP indicates the number of non-landslide pixels classified as landslides pixels, and FN indicates the number of actual landslide pixels classified as non-landslides pixels. The confusion matrix accuracy, precision, recall, root mean square error (RMSE), and mean absolute error (MAE) values were calculated. Receiver operating characteristic (ROC) curves with area under curve (AUC) values are generally used to access the classification performance. The higher the AUC's value, the better the model is for accurately predicting the landslide and nonlandslide pixels. The landslide inventory training dataset was used to generate the AUC prediction curve, while the validation dataset was used to generate the AUC validation curve and performance matrices. It was found that the SE-FR and SE-SVM models had training accuracies with $\mathrm{AUC}=96.933$ and $\mathrm{AUC}=94.053$, respectively. In contrast, the prediction capability of the models had AUC $=88.945$ and $\mathrm{AUC}=82.4$ values, respectively (Figure 5). In terms of the results obtained from the confusion matrices, the SE-FR and SE-SVM models had values for accuracy of 0.896 and 0.854 , precision of 0.958 and 0.931 , respectively, and recall of 0.814 and 0.790 , respectively. The MAE and RMSE values of the SE-FR and SE-SVM models were 0.135 and 0.174 , and 0.295 and 0.347 , respectively as shown in Table 6 . The results of the prediction matrices indicate that both models have good accuracies, prediction, and recall values, and the MAE and RMSE errors generated in both models are under acceptable limits. Based on these statistical and visual performance metrics, it can be found that both models have a good predictive potential and acceptable values of errors.
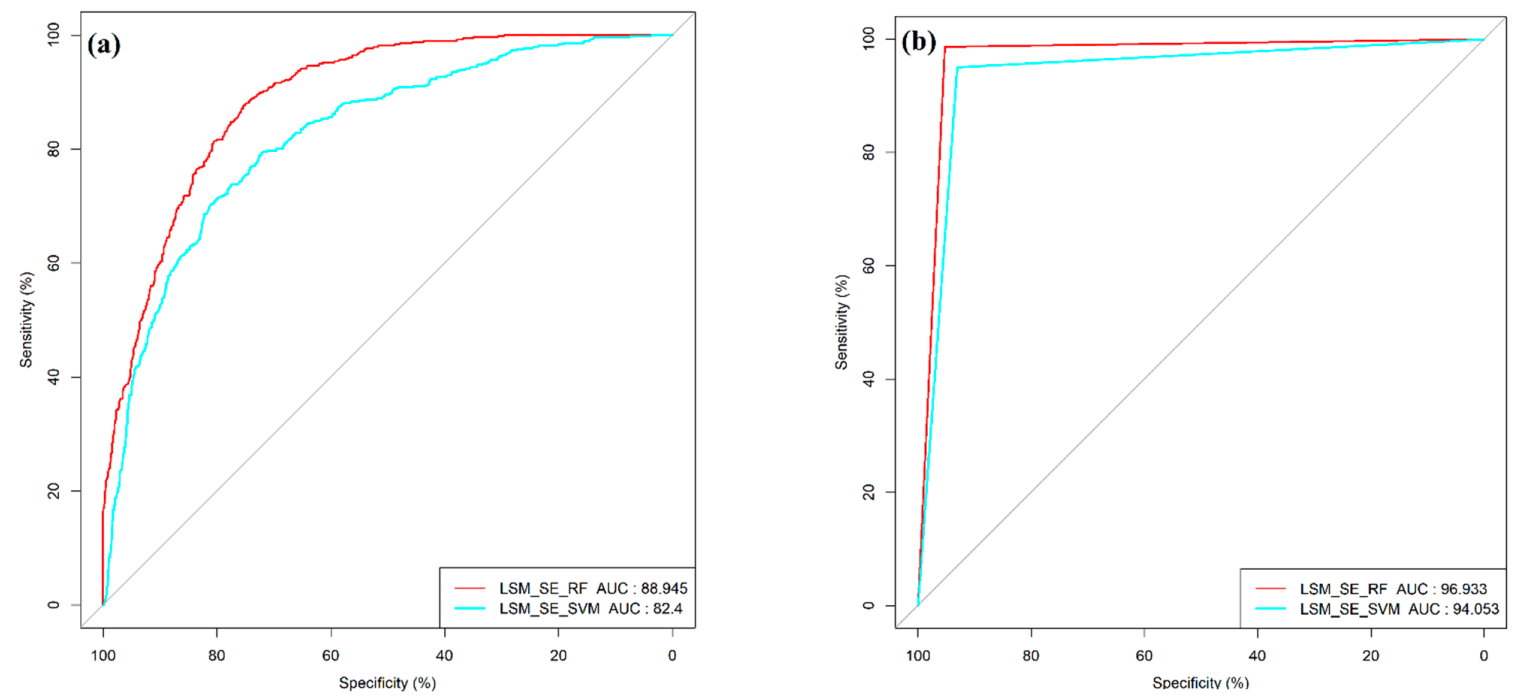

Figure 5. ROC curves with AUC values: (a) AUC prediction and (b) AUC validation. 
Table 6. Performance metrics for the model comparison.

\begin{tabular}{cccccccc}
\hline Model & Accuracy & $\begin{array}{c}\text { AUC } \\
\text { Prediction }\end{array}$ & $\begin{array}{c}\text { AUC } \\
\text { Validation }\end{array}$ & MAE & RMSE & Precision & Recall \\
\hline SE-RF & 0.8963 & 88.94 & 96.93 & 0.1354 & 0.2956 & 0.9589 & 0.8144 \\
SE-SVM & 0.8541 & 82.40 & 94.05 & 0.1747 & 0.3479 & 0.9314 & 0.7902 \\
\hline
\end{tabular}

\section{Discussion}

Statistical and ML modeling is an essential component for determining the landslide susceptibility of an area. The accuracy of statistical models depends on the data quality, appropriate landslide causative factors, and model structure. The process of the generation of landslide susceptibility maps is complex and requires a multistep analysis. The present study focusses on three main issues: (a) the optimum selection of landslide causative factors using feature selection process, (b) the mapping of landslide susceptibility of Mandi District using hybrid SE-RF and SE-SVM models, and (c) the comparison of these two hybrid models based on performance matrices. In the present study, 14 LCFs were evaluated to find the optimum subset. It was found that the feature selection process, which used a hybrid approach, resulted in the selection of 11 optimum feature subsets.

The analysis of the LSMs produced using SE-RF and SE-SVM models indicated that areas with high TWI values, particularly in the $0-100 \mathrm{~m}$ distance to roads, are highly prone to landslides. In mountainous regions like the study area, the continuous excavation of slopes for road construction activities and the infiltration of water, especially during monsoon season, results in an increased burden on slopes. The soil mass in such areas becomes unstable and often results in sliding. Lower elevation regions have seen such anthropological activities on a larger scale than the higher elevation regions of the study area. In addition, higher-elevation regions have less accessibility, and few landslides are reported.

Similarly, the analysis of the geology map confirms that the Middle Siwalik Group was highly prone to landslides due to the presence of sedimentary rocks like mediumto coarse-grained sandstone and conglomerate. The rest of the causative factors, such as curvature, aspect, and lineaments, have a lower influence on the landslide susceptibility of the region. Such a combination of LCF's is seen in similar studies of mountainous regions [5,11,12,36,48,70,81].

RF and SVM are two highly efficient machine learning models that can tackle complex non-linear relationships among variables, and are readily used by researchers in classification problems. FR is a combined tree-based model that can handle high dimensional spaces and categorical features with a high accuracy and is easily interpretable. A disadvantage of the RF model is its incapacity to calculate the relative importance of each subclass of the landslide causative factors. SVM uses "support vectors" and performs better when data are sparce and non-linearly separable. SVM has the advantage of having non-linear kernel functions but has a higher tendency of overfitting. SE is a statistical bivariate model that can calculate the factors' relative weights and subclasses with relative ease and minimal time consumption. The analysis of the results of this study indicated that the integration of SE-RF and SE-SVM models resulted in increased accuracy and efficiency for both models.

In comparison with each other, the SE-RF model performed better than the SE-SVM model. The SE-SVM model has a $+2.88 \%$ higher AUC for model validation and $+6.54 \%$ higher AUC for model prediction. The performance matrices also indicated an increase in $+4.2 \%$ accuracy and $+2.7 \%$ precision, with a $3.9 \%$ decrease in MAE and $5.2 \%$ decrease in RMSE errors. This may be attributed to the overdependence of the SVM model on data pre-processing and kernel functions. Such results are consistent with the findings of [80] who combined LR and SVM with the IOE method, who combined EBF method with RF to obtain landslide susceptibility, who used an ensemble of WOE with different kernel functions of SVM, and who used various DEM's and an integrated FR-RF model for assessment of the landslide susceptibility. Thus, using a hybrid approach to integrate 
statistical and ML models helps eliminate the disadvantages of individual models and increases the overall efficiency prediction capabilities of the models.

\section{Conclusions}

The analysis of landslide susceptibility is the primary step in managing and mitigating landslide risk in a mountainous region. Many statistical and ML algorithms have been used in recent years, but no definitive method is considered best for preparing the LSM of a region. The hybrid integration of these methods has the advantage of a better prediction potential compared with individual models. In the present study, a statistical SE model is integrated with RF and SVM models to overcome the shortcomings of the individual method. A total of $14 \mathrm{LCF}$ (slope gradient, plan curvature, slope aspect, elevation, drainage density, lithology, geology, land use and landcover (LULC), normalized difference vegetation index (NDVI), soil characteristics, lineament density, stream power index (SPI), topographic wetness index (TWI), and distance from the roads) were identified. A feature selection process was carried out using two feature ranking algorithms, i.e., information gain and Chi-square, which were used to determine the individual scores of the LCFs, and Wilcoxon signed-rank test and One-Sample T-Test were used to determine the statistical significance of the factors. The results of both hybrid models indicated TWI and distance from roads to be the two primary factors responsible for landslide occurrences in the study area. The results also indicated that although both models performed satisfactorily, the SE-RF model had $+2.88 \%$ and $+6.54 \%$ higher AUC values than the SE-SVM model. The main advantage of such an approach is that only relevant LCFs were used to generate the LSM. The integration of models helps establish an effective spatial relationship between landslide occurrences and LCFs, while reducing overfitting problems. This study will help regional planners and stakeholders in effective landslide risk management and sustainable developmental activities.

Author Contributions: Conceptualization, A.S. and C.P.; methodology, A.S. and C.P.; software, A.S.; formal analysis, A.S.; investigation, A.S., C.P. and V.S.M.; resources, A.S.; data curation, A.S.; validation, A.S.; visualization, A.S., C.P. and V.S.M.; writing — original draft preparation, A.S.; writingreview and editing, A.S., C.P. and V.S.M.; supervision, C.P. and V.S.M. All authors have read and agreed to the published version of the manuscript.

Funding: This research received no external funding.

Conflicts of Interest: The authors declared no conflict of interest.

\section{References}

1. Ali, S.A.; Parvin, F.; Vojteková, J.; Costache, R.; Linh, N.T.T.; Pham, Q.B.; Vojtek, M.; Gigović, L.; Ahmad, A.; Ghorbani, M.A. GIS-based landslide susceptibility modeling: A comparison between fuzzy multi-criteria and machine learning algorithms. Geosci. Front. 2020, 12, 857-876. [CrossRef]

2. Wang, G.; Lei, X.; Chen, W.; Shahabi, H.; Shirzadi, A. Hybrid Computational Intelligence Methods for Landslide Susceptibility Mapping. Symmetry 2020, 12, 325. [CrossRef]

3. Landslides. Available online: https://www.who.int/health-topics/landslides\#tab=tab_1 (accessed on 15 September 2021).

4. Revenue Department, Government of Himachal Pradesh. Memorandum of Damages Due to Flash Floods, Cloudbursts and Landslides during Monsoon Season-2020; HPSDMA: Shimla, India, 2020; pp. 14-26.

5. Zhao, X.; Chen, W. Optimization of Computational Intelligence Models for Landslide Susceptibility Evaluation. Remote Sens. 2020, 12, 2180. [CrossRef]

6. Nohani, E.; Moharrami, M.; Sharafi, S.; Khosravi, K.; Pradhan, B.; Pham, B.T.; Lee, S.; Melesse, A.M. Landslide Susceptibility Mapping Using Different GIS-Based Bivariate Models. Water 2019, 11, 1402. [CrossRef]

7. Nayak, J.; Westen, C.V.; Das, I.C.; Nayak, J. Landslide Risk Assessment along a Major Road Corridor Based on Historical Landslide Inventory and Traffic Analysis; University of Twente Faculty of Geo-Information and Earth Observation (ITC): Enschede, The Netherlands, 2010; p. 104.

8. Reichenbach, P.; Rossi, M.; Malamud, B.; Mihir, M.; Guzzetti, F. A review of statistically-based landslide susceptibility models. Earth-Sci. Rev. 2018, 180, 60-91. [CrossRef]

9. Feizizadeh, B.; Jankowski, P.; Blaschke, T. A GIS based spatially-explicit sensitivity and uncertainty analysis approach for multi-criteria decision analysis. Comput. Geosci. 2013, 64, 81-95. [CrossRef] 
10. Saha, A.; Saha, S. Comparing the efficiency of weight of evidence, support vector machine and their ensemble approaches in landslide susceptibility modelling: A study on Kurseong region of Darjeeling Himalaya, India. Remote Sens. Appl. Soc. Environ. 2020, 19, 100323. [CrossRef]

11. Arabameri, A.; Karimi-Sangchini, E.; Pal, S.; Saha, A.; Chowdhuri, I.; Lee, S.; Bui, D.T. Novel Credal Decision Tree-Based Ensemble Approaches for Predicting the Landslide Susceptibility. Remote Sens. 2020, 12, 3389. [CrossRef]

12. Chen, W.; Pourghasemi, H.R.; Panahi, M.; Kornejady, A.; Wang, J.; Xie, X.; Cao, S. Spatial prediction of landslide susceptibility using an adaptive neuro-fuzzy inference system combined with frequency ratio, generalized additive model, and support vector machine techniques. Geomorphology 2017, 297, 69-85. [CrossRef]

13. Shahabi, H.; Khezri, S.; Bin Ahmad, B.; Hashim, M. RETRACTED: Landslide susceptibility mapping at central Zab basin, Iran: A comparison between analytical hierarchy process, frequency ratio and logistic regression models. CATENA 2014, 115, 55-70. [CrossRef]

14. Galli, M.; Ardizzone, F.; Cardinali, M.; Guzzetti, F.; Reichenbach, P. Comparing landslide inventory maps. Geomorphology 2008, 94, 268-289. [CrossRef]

15. Ngadisih; Bhandary, N.P.; Yatabe, R.; Dahal, R.K. Logistic regression and artificial neural network models for mapping of regional-scale landslide susceptibility in volcanic mountains of West Java (Indonesia). AIP 2016, 1730, 60001. [CrossRef]

16. Sharma, R.K.; Mehta, B.S. Macro-zonation of landslide susceptibility in Garamaura-Swarghat-Gambhar section of national highway 21, Bilaspur District, Himachal Pradesh (India). Nat. Hazards 2011, 60, 671-688. [CrossRef]

17. Banshtu, R.S.; Prakash, C. Application of Remote Sensing and GIS Techniques in Landslide Hazard Zonation of Hilly Terrain; Springer: Cham, Switzerland, 2014; pp. 313-317. [CrossRef]

18. Lee, S.; Lee, M.-J.; Jung, H.-S.; Lee, S. Landslide Susceptibility Mapping Using Naïve Bayes and Bayesian Network Models in Umyeonsan, Korea. Geocarto Int. 2019, 35, 1665-1679. [CrossRef]

19. Bui, D.T.; Shahabi, H.; Shirzadi, A.; Chapi, K.; Alizadeh, M.; Chen, W.; Mohammadi, A.; Bin Ahmad, B.; Panahi, M.; Hong, H.; et al. Landslide Detection and Susceptibility Mapping by AIRSAR Data Using Support Vector Machine and Index of Entropy Models in Cameron Highlands, Malaysia. Remote Sens. 2018, 10, 1527. [CrossRef]

20. Alvioli, M.; Mondini, A.; Fiorucci, F.; Cardinali, M.; Marchesini, I. Automatic Landslide Mapping from Satellite Imagery with a Topography-Driven Thresholding Algorithm. PeerJ Prepr. 2018, 1-4. [CrossRef]

21. Nagarajan, R.; Mukherjee, A.; Roy, A.; Khire, M.V. Technical note Temporal remote sensing data and GIS application in landslide hazard zonation of part of Western ghat, India. Int. J. Remote Sens. 1998, 19, 573-585. [CrossRef]

22. Bui, D.T.; Pradhan, B.; Lofman, O.; Revhaug, I.; Dick, O.B. Spatial prediction of landslide hazards in Hoa Binh province (Vietnam): A comparative assessment of the efficacy of evidential belief functions and fuzzy logic models. CATENA 2012, 96, 28-40. [CrossRef]

23. Shahri, A.A.; Spross, J.; Johansson, F.; Larsson, S. Landslide susceptibility hazard map in southwest Sweden using artificial neural network. CATENA 2019, 183, 104225. [CrossRef]

24. Frangov, G.; Petkova, V.; Stoyanov, V.; Kadiyski, M.; Kostov, V.; Papaliangas, T. Landslide Risk Assessment and Mitigation Along a Road in Sw Bulgaria. Fresenius Environ. Bull. 2017, 26, 244-253.

25. Pradhan, B.; Abokharima, M.H.; Jebur, M.N.; Tehrany, M.S. Land subsidence susceptibility mapping at Kinta Valley (Malaysia) using the evidential belief function model in GIS. Nat. Hazards 2014, 73, 1019-1042. [CrossRef]

26. Mandal, S.; Mondal, S. Statistical Approaches for Landslide Susceptibility Assessment and Prediction; Springer International Publishing: Cham, Switzerland, 2019. Available online: https:/ / doi.org/10.1007/978-3-319-93897-4 (accessed on 25 September 2020).

27. Ozdemir, A.; Altural, T. A comparative study of frequency ratio, weights of evidence and logistic regression methods for landslide susceptibility mapping: Sultan Mountains, SW Turkey. J. Asian Earth Sci. 2013, 64, 180-197. [CrossRef]

28. Zare, M.; Jouri, M.H.; Salarian, T.; Askarizadeh, D. Comparing of Bivariate Statistic, AHP and Combination Methods to Predict the Landslide Hazard in Northern Aspect of Alborz Mt (Iran). Int. J. Agric. Crop Sci. 2014, 7, 543-554.

29. Chen, W.; Xie, X.; Peng, J.; Shahabi, H.; Hong, H.; Bui, D.T.; Duan, Z.; Li, S.; Zhu, A.-X. GIS-based landslide susceptibility evaluation using a novel hybrid integration approach of bivariate statistical based random forest method. CATENA 2018, 164, 135-149. [CrossRef]

30. Devkota, K.C.; Regmi, A.D.; Pourghasemi, H.R.; Yoshida, K.; Pradhan, B.; Ryu, I.C.; Dhital, M.R.; Althuwaynee, O.F. Landslide susceptibility mapping using certainty factor, index of entropy and logistic regression models in GIS and their comparison at Mugling-Narayanghat road section in Nepal Himalaya. Nat. Hazards 2012, 65, 135-165. [CrossRef]

31. Liu, W.; Song, Z. Review of studies on the resilience of urban critical infrastructure networks. Reliab. Eng. Syst. Saf. 2019, 193, 106617. [CrossRef]

32. Pourghasemi, H.R.; Pradhan, B.; Gokceoglu, C. Remote Sensing Data Derived Parameters and its Use in Landslide Susceptibility Assessment Using Shannon's Entropy and GIS. Appl. Mech. Mater. 2012, 225, 486-491. [CrossRef]

33. Milaghardan, A.H.; Abbaspour, R.A.; Khalesian, M. Evaluation of the effects of uncertainty on the predictions of landslide occurrences using the Shannon entropy theory and Dempster-Shafer theory. Nat. Hazards 2019, 100, 49-67. [CrossRef]

34. Roodposhti, M.S.; Aryal, J.; Shahabi, H.; Safarrad, T. Fuzzy Shannon Entropy: A Hybrid GIS-Based Landslide Susceptibility Mapping Method. Entropy 2016, 18, 343. [CrossRef]

35. Roy, J.; Saha, S.; Arabameri, A.; Blaschke, T.; Bui, D.T. A Novel Ensemble Approach for Landslide Susceptibility Mapping (LSM) in Darjeeling and Kalimpong Districts, West Bengal, India. Remote Sens. 2019, 11, 2866. [CrossRef] 
36. Yusof, N.M.; Pradhan, B.; Shafri, H.Z.M.; Jebur, M.N.; Yusoff, Z.M. Spatial landslide hazard assessment along the Jelapang Corridor of the North-South Expressway in Malaysia using high resolution airborne LiDAR data. Arab. J. Geosci. 2015, 8, 9789-9800. [CrossRef]

37. Pradhan, A.M.S.; Kim, Y.-T. Spatial data analysis and application of evidential belief functions to shallow landslide susceptibility mapping at Mt. Umyeon, Seoul, Korea. Bull. Int. Assoc. Eng. Geol. 2016, 76, 1263-1279. [CrossRef]

38. Budimir, M.E.A.; Atkinson, P.M.; Lewis, H.G. A systematic review of landslide probability mapping using logistic regression. Landslides 2015, 12, 419-436. [CrossRef]

39. Yousefi, S.; Pourghasemi, H.R.; Emami, S.N.; Pouyan, S.; Eskandari, S.; Tiefenbacher, J.P. A machine learning framework for multi-hazards modeling and mapping in a mountainous area. Sci. Rep. 2020, 10, 1-14. [CrossRef]

40. Saha, S.; Paul, G.C.; Pradhan, B.; Maulud, K.N.A.; Alamri, A.M. Integrating multilayer perceptron neural nets with hybrid ensemble classifiers for deforestation probability assessment in Eastern India. Geomat. Nat. Hazards Risk 2020, 12, 29-62. [CrossRef]

41. Chang, K.-T.; Merghadi, A.; Yunus, A.P.; Pham, B.T.; Dou, J. Evaluating scale effects of topographic variables in landslide susceptibility models using GIS-based machine learning techniques. Sci. Rep. 2019, 9, 1-21. [CrossRef]

42. Sahin, E.K.; Colkesen, I.; Acmali, S.S.; Akgun, A.; Aydinoglu, A.C. Developing comprehensive geocomputation tools for landslide susceptibility mapping: LSM tool pack. Comput. Geosci. 2020, 144, 104592. [CrossRef]

43. Dou, J.; Bui, D.T.; Yunus, A.P.; Jia, K.; Song, X.; Revhaug, I.; Xia, H.; Zhu, Z. Optimization of Causative Factors for Landslide Susceptibility Evaluation Using Remote Sensing and GIS Data in Parts of Niigata, Japan. PLoS ONE 2015, 10, e0133262. [CrossRef]

44. Hong, H.; Liu, J.; Zhu, A.-X. Modeling landslide susceptibility using LogitBoost alternating decision trees and forest by penalizing attributes with the bagging ensemble. Sci. Total Environ. 2020, 718, 137231. [CrossRef]

45. Pham, B.T.; Bui, D.T.; Prakash, I.; Dholakia, M.B. Rotation forest fuzzy rule-based classifier ensemble for spatial prediction of landslides using GIS. Nat. Hazards 2016, 83, 97-127. [CrossRef]

46. Duch, W.; Wieczorek, T.; Biesiada, J.; Blachnik, M. Comparison of feature ranking methods based on information entropy. In Proceedings of the 2004 IEEE International Joint Conference on Neural Networks, Budapest, Hungary, 25-29 July 2004; Volume 2, pp. 1415-1419. [CrossRef]

47. Nguyen, V.V.; Pham, B.T.; Vu, B.T.; Prakash, I.; Jha, S.; Shahabi, H.; Shirzadi, A.; Ba, D.N.; Kumar, R.; Chatterjee, J.M.; et al. Hybrid Machine Learning Approaches for Landslide Susceptibility Modeling. Forests 2019, 10, 157. [CrossRef]

48. Pradhan, B.; Lee, S. Landslide susceptibility assessment and factor effect analysis: Backpropagation artificial neural networks and their comparison with frequency ratio and bivariate logistic regression modelling. Environ. Model. Softw. 2010, 25, 747-759. [CrossRef]

49. Youssef, A.M.; Pourghasemi, H.R. Landslide susceptibility mapping using machine learning algorithms and comparison of their performance at Abha Basin, Asir Region, Saudi Arabia. Geosci. Front. 2020, 12, 639-655. [CrossRef]

50. Polykretis, C.; Chalkias, C. Comparison and evaluation of landslide susceptibility maps obtained from weight of evidence, logistic regression, and artificial neural network models. Nat. Hazards 2018, 93, 249-274. [CrossRef]

51. Dou, J.; Yunus, A.P.; Bui, D.T.; Merghadi, A.; Sahana, M.; Zhu, Z.; Chen, C.-W.; Khosravi, K.; Yang, Y.; Pham, B.T. Assessment of advanced random forest and decision tree algorithms for modeling rainfall-induced landslide susceptibility in the Izu-Oshima Volcanic Island, Japan. Sci. Total Environ. 2019, 662, 332-346. [CrossRef] [PubMed]

52. Chen, W.; Xie, X.; Peng, J.; Wang, J.; Duan, Z.; Hong, H. GIS-based landslide susceptibility modelling: A comparative assessment of kernel logistic regression, Naïve-Bayes tree, and alternating decision tree models. Geomat. Nat. Hazards Risk 2017, 8, 950-973. [CrossRef]

53. Huang, Y.; Zhao, L. Review on landslide susceptibility mapping using support vector machines. CATENA 2018, 165, 520-529. [CrossRef]

54. Merghadi, A.; Yunus, A.P.; Dou, J.; Whiteley, J.; ThaiPham, B.; Bui, D.T.; Avtar, R.; Abderrahmane, B. Machine learning methods for landslide susceptibility studies: A comparative overview of algorithm performance. Earth-Sci. Rev. 2020, 207, 103225. [CrossRef]

55. Chen, W.; Zhang, S.; Li, R.; Shahabi, H. Performance evaluation of the GIS-based data mining techniques of best-first decision tree, random forest, and naïve Bayes tree for landslide susceptibility modeling. Sci. Total Environ. 2018, 644, 1006-1018. [CrossRef] [PubMed]

56. Li, Y.; Chen, W. Landslide Susceptibility Evaluation Using Hybrid Integration of Evidential Belief Function and Machine Learning Techniques. Water 2019, 12, 113. [CrossRef]

57. Chen, X.; Chen, W. GIS-based landslide susceptibility assessment using optimized hybrid machine learning methods. CATENA 2020, 196, 104833. [CrossRef]

58. Survey, C.G.; Paper, C.; John, C.; California, W.; Survey, G.; Ca, S.; Calif, B.S.; Survey, G. Landslide Inventory Maps of Highway Corridors in California. In Proceedings of the 3rd North American Symposium on Landslides, Roanoke, VA, USA, 4-8 June 2017; pp. 529-540.

59. Varnes, D.J. Landslide Hazard Zonation A Review of Principles and Practice, Natural Hazards; UNESCO: Paris, France, 1984. Available online: https://www.scirp.org/(S(351jmbntvnsjt1aadkposzje))/reference/ReferencesPapers.aspx?ReferenceID=1768332 (accessed on 6 August 2021).

60. Fell, R. Landslide risk assessment and acceptable risk. Can. Geotech. J. 1994, 31, 261-272. [CrossRef] 
61. Arca, D.; Citiroglu, H.K.; Tasoglu, I.K. A comparison of GIS-based landslide susceptibility assessment of the Satuk village (Yenice, NW Turkey) by frequency ratio and multi-criteria decision methods. Environ. Earth Sci. 2019, 78, 81. [CrossRef]

62. Jiménez-Perálvarez, J.D.; Irigaray, C.; El Hamdouni, R.; Chacón, J. Landslide-susceptibility mapping in a semi-arid mountain environment: An example from the southern slopes of Sierra Nevada (Granada, Spain). Bull. Int. Assoc. Eng. Geol. 2010, 70, 265-277. [CrossRef]

63. Chen, W.; Fan, L.; Li, C.; Pham, B.T. Spatial Prediction of Landslides Using Hybrid Integration of Artificial Intelligence Algorithms with Frequency Ratio and Index of Entropy in Nanzheng County, China. Appl. Sci. 2019, 10, 29. [CrossRef]

64. Pradhan, B. Remote sensing and GIS-based landslide hazard analysis and cross-validation using multivariate logistic regression model on three test areas in Malaysia. Adv. Space Res. 2010, 45, 1244-1256. [CrossRef]

65. Choubey, V.M.; Mukherjee, P.K.; Bajwa, B.J.S.; Walia, V. Geological and tectonic influence on water-soil-radon relationship in Mandi-Manali area, Himachal Himalaya. Environ. Earth Sci. 2006, 52, 1163-1171. [CrossRef]

66. Baum, R.L.; Godt, J. Early warning of rainfall-induced shallow landslides and debris flows in the USA. Landslides 2009, 7, 259-272. [CrossRef]

67. Chen, W.; Li, Y. GIS-based evaluation of landslide susceptibility using hybrid computational intelligence models. CATENA 2020, 195, 104777. [CrossRef]

68. Lee, S.; Talib, J.A. Probabilistic landslide susceptibility and factor effect analysis. Environ. Earth Sci. 2005, 47, 982-990. [CrossRef]

69. Tsangaratos, P.; Ilia, I. Comparison of a logistic regression and Naïve Bayes classifier in landslide susceptibility assessments: The influence of models complexity and training dataset size. CATENA 2016, 145, 164-179. [CrossRef]

70. Liu, L.-L.; Yang, C.; Wang, X.-M. Landslide Susceptibility Assessment Using Feature Selection-Based Machine Learning Models. Geomech. Eng. 2020, 25, 1-16.

71. Laborda, J.; Ryoo, S. Feature Selection in a Credit Scoring Model. Mathematics 2021, 9, 746. [CrossRef]

72. Breiman, L. Random Forests. Mach. Learn. 2001, 45, 5-32. [CrossRef]

73. Cortes, C.; Vapnik, V. Support-vector networks. Mach. Learn. 1995, 20, 273-297. [CrossRef]

74. Micheletti, N.; Foresti, L.; Robert, S.; Leuenberger, M.; Pedrazzini, A.; Jaboyedoff, M.; Kanevski, M. Machine Learning Feature Selection Methods for Landslide Susceptibility Mapping. Math. Geol. 2013, 46, 33-57. [CrossRef]

75. Dou, J.; Yunus, A.P.; Bui, D.T.; Merghadi, A.; Sahana, M.; Zhu, Z.; Chen, C.-W.; Han, Z.; Pham, B.T. Improved landslide assessment using support vector machine with bagging, boosting, and stacking ensemble machine learning framework in a mountainous watershed, Japan. Landslides 2019, 17, 641-658. [CrossRef]

76. Cigdem, O.; Demirel, H. Performance analysis of different classification algorithms using different feature selection methods on Parkinson's disease detection. J. Neurosci. Methods 2018, 309, 81-90. [CrossRef]

77. Zhang, T.; Han, L.; Chen, W.; Shahabi, H. Hybrid Integration Approach of Entropy with Logistic Regression and Support Vector Machine for Landslide Susceptibility Modeling. Entropy 2018, 20, 884. [CrossRef]

78. Dou, J.; Yunus, A.P.; Bui, D.T.; Sahana, M.; Chen, C.-W.; Zhu, Z.; Wang, W.; Pham, B.T. Evaluating GIS-Based Multiple Statistical Models and Data Mining for Earthquake and Rainfall-Induced Landslide Susceptibility Using the LiDAR DEM. Remote Sens. 2019, 11, 638. [CrossRef]

79. Pourghasemi, H.R.; Kerle, N. Random forests and evidential belief function-based landslide susceptibility assessment in Western Mazandaran Province, Iran. Environ. Earth Sci. 2016, 75, 1-17. [CrossRef]

80. Arabameri, A.; Saha, S.; Roy, J.; Chen, W.; Blaschke, T.; Bui, D.T. Landslide Susceptibility Evaluation and Management Using Different Machine Learning Methods in The Gallicash River Watershed, Iran. Remote Sens. 2020, 12, 475. [CrossRef]

81. Arabameri, A.; Pradhan, B.; Rezaei, K.; Lee, C.-W. Assessment of Landslide Susceptibility Using Statistical- and Artificial Intelligence-based FR-RF Integrated Model and Multiresolution DEMs. Remote Sens. 2019, 11, 999. [CrossRef] 